Jurnal Pendidikan Biologi Jurnal

Volume 4, Nomor 1, Maret 2021
$\mathbf{D}$

\title{
PENINGKATAN HASIL BELAJAR MELALUI MODEL AUDITORY INTELECTUALY REPETITION (AIR) DAN MODEL THINK TALK WRITE (TTW)
}

\author{
Wiwik Wiji Astuti \\ Program Studi Pendidikan Biologi, STKIP Pembangunan Indonesia Makassar, \\ wiwikwijiastuti@gmail.com
}

\begin{abstract}
Abstrak
Penelitian ini adalah penelitian eksperimen semu (quasy experiment) yang bertujuan untuk mengetahui hasil belajar siswa kelas VIII SMP Negeri 5 Bittuang yang diajar menggunakan model pembelajaran Auditory Intelectually Repetition (AIR), mengetahui hasil belajar siswa kelas VIII SMP Negeri 5 Bittuang yang diajar menggunakan model pembelajaran Think Talk Write (TTW), mengetahui perbedaan hasil belajar siswa yang diajar dengan model pembelajaran Auditory Intelectually Repetition (AIR) dan model pembelajaran Think Talk Write (TTW). Subjek penelitian ini adalah siswa Kelas VIIIa dan Kelas VIIIb SMP Negeri 5 Bittuang Tana Toraja. Instrumen yang digunakan dalam penelitian ini adalah lembar observasi dan tes hasil belajar biologi siswa. Analisis data dilakukan dengan menggunakan analisis statistik deskriptif dan analisis statistik inferensial. Hasil penelitian menunjukkan bahwa nilai rata-rata hasil belajar siswa pada model pembelajaran Auditory Intelectually Repetition (AIR) berada pada kategori sangat tinggi dengan nilai rata-rata yakni 76,40 sedangkan model pembelajaran Think Talk Write (TTW) berada pada kategori sedang dengan nilai rata-rata yakni 64,79. Selain itu data hasil penelitian menunjukkan bahwa terdapat perbedaan hasil belajar siswa antara model Pembelajaran Auditory Intelectually Repitition (AIR) dengan kelompok model pembelajaran Think Talk Write (TTW) pada materi sistem gerak pada manusia di kelas VIII SMPN 5 Bittuang Tana Toraja tahun ajaran 2017/2018.
\end{abstract}

\begin{abstract}
This research is a quasy experiment research which aims to determine the learning outcomes of class VIII students of SMP Negeri 5 Bittuang who are taught using the Auditory Intelectually Repetition (AIR) learning model, knowing the learning outcomes of grade VIII students of SMP Negeri 5 Bittuang who are taught using the learning model. Think Talk Write (TTW), finds out the differences in student learning outcomes taught by the Auditory Intelectually Repetition (AIR) learning model and the Think Talk Write (TTW) learning model. The subjects of this study were students of Class VIIIa and Class VIIIb of SMP Negeri 5 Bittuang Tana Toraja. The instruments used in this study were observation sheets and student biology learning outcomes tests. Data analysis was performed using descriptive statistical analysis and inferential statistical analysis. The results showed that the average value of student learning outcomes in the Auditory Intelectually Repetition
\end{abstract}


(AIR) learning model was in the very high category with an average value of 76.40 while the Think Talk Write (TTW) learning model was in the medium category with an average score. -The average is 64.79. In addition, the research data shows that there are differences in student learning outcomes between the Auditory Intelectually Repitition (AIR) learning model and the Think Talk Write (TTW) learning model group on human movement system material in class VIII SMPN 5 Bittuang Tana Toraja for the 2017/2018 school year.

Kata Kunci: Auditory Intelectually Repitition (AIR), Think Talk Write (TTW), Hasil Belajar

\section{PENDAHULUAN}

Pendidikan merupakan salah satu tombak ujung dalam pembangunan suatu bangsa. Melalui pendidikan peningkatan kualitas sumber daya manusia dapat dilakukan sehingga setiap warga negara memiliki bekal keterampilan dan kecakapan hidup di dunia lapangan kerja. Sesuai dengan pendapat Musanna, Al, (2017) dan Karagoz, O., \& Saka, A. Z. (2015). bahwa Pendidikan menempati posisi strategis dalam peningkatan kualitas dan kapasitas seseorang untuk mengarungi kehidupan.

\section{Menurut UU SISDIKNAS}

No.20 (2003) dan Wasti, S., Rahmiati \& Izwerni. (2013) bahwa pendidikan adalah usaha sadar dan terencana untuk mewujudkan suasana belajar dan proses pembelajaran agar peserta didik secara aktif mengembangkan potensi dirinya untuk memiliki kekuatan spiritual keagamaan, pengendalian diri, kepribadian, kecerdasan, akhlak mulia, serta keterampilan yang diperlukan dirinya dan masyarakat.

Proses pembelajaran di kelas sangat dipengaruhi oleh kemampuan guru dalam memilih dan menentukan model pembelajaran yang tepat dan sesuai dengan kondisi peserta didik. (Fahri, M. B. P. 2014).

Model pembelajaran adalah suatu perencanaan atau pola yang digunakan sebagai pedoman dalam merencanakan pembelajaran di kelas atau pembelajaran tutorial. Model pembelajaran mengacu pada pendekatan pembelajaran yang akan digunakan, termasuk di dalamnya tujuan-tujuan pengajaran, tahap-tahap dalam kegiatan pembelajaran, lingkungan dan 
pembelajaran serta pengelolaan kelas (Trianto, 2010).

Melalui penggunaan model pembelajaran yang tepat dapat membantu siswa dalam memahami materi pelajaran yang berdampak positif terhadap peningkatan hasil belajarnya. (Fikri, B. M. 2014).

Berdasarkan hasil observasi yang dilakukan di Kelas VIII SMP Negeri 5 Bittuang diperoleh data bahwa hasil belajar biologi siswa khususnya pada materi sistem gerak, masih rendah yakni di bawah KKM (Kriteria Ketuntasan Minimal) yaitu nilai 70 . Kondisi ini disebabkan karena guru belum menemukan model pembelajaran yang tepat dan sesuai karakteristik materi yang diajarkan. Pada umumnya guru hanya menerapkan model pembelajaran konvensional yang mengakibatkan siswa menjadi pasif dalam menerima materi pelajaran dan berpengaruh terhadap rendahnya motivasi dan hasil belajarnya.

Materi sistem gerak pada manusia mempunyai karakteristik khusus yaitu membahas materi tentang struktur dan fungsi dari alat gerak serta gangguan atau kelainan yang terjadi pada sistem gerak.
Pada materi sistem gerak ini, siswa juga mengalami kesulitan untuk mengingat dan menghafal serta menyebutkan nama-nama latin dari tulang. Sehingga sangat dibutuhkan adanya inovasi dari guru untuk dapat memilih model pembelajaran yang tepat dalam proses pembelajaran.

Model pembelajaran Auditory

\section{Intellectualy Repetition}

(AIR) menjadikan siswa dapat ikut aktif dalam proses pembelajaran sehingga tercipta proses pembelajaran yang hidup dan tidak hanya berpusat pada guru. Selain itu model pembelajaran Auditory Intellectualy Repetition menerapkan jika belajar juga harus dengan pengulangan (repetition). Pengulangan yang bertujuan untuk lebih mengingat kembali materi pelajaran yang telah diajarkan (Elinawati, W., Duda, H.J., Julung, H., 2018).

Model TTW mendorong peserta didik untuk berpikir, berbicara, dan kemudian menuliskan suatu topik tertentu. Model ini digunakan untuk mengembangkan tulisan dengan lancar dan melatih bahasa sebelum dituliskan. Model TTW memperkenalkan peserta didik untuk mempengaruhi dan memanipulasi ide-ide sebelum 
menuangkannya dalam bentuk tulisan. Ia juga membantu peserta didik dalam mengumpulkan dan mengembangkan ide-ide melalui percakapan terstruktur (Winarti, A., 2018).

Berdasarkan uraian diatas, maka penulis tertarik untuk melakukan penelitian dengan judul "Perbandingan Hasil Belajar Melalui Model Pembelajaran Auditory Intelectualy Repetition (AIR) dan Model Pembelajaran Think Talk Write (TTW) pada Materi Sistem Gerak pada Manusia di Kelas VIII SMP Negeri 5 Bittuang".

\section{METODE PENELITIAN}

Penelitian ini merupakan penelitian eksperimen semu (quasi eksperimen). Kelompok penelitian dibagi menjadi dua kelompok eksperimen, yaitu kelompok pertama adalah kelompok eksperimen yang diajar dengan menggunakan model pembelajaran Auditory Intelectualy Repitition (AIR) dan kelompok kedua adalah kelompok eksperimen yang diajar dengan menggunakan model pembelajaran kooperatif tipe Think Talk Write (TTW).

Desain penelitian yang digunakan adalah post test-only control design. Populasi dalam penelitian ini adalah keseluruhan siswa kelas VIII SMP Negeri 5 Bittuang. Sampel yang digunakan terdiri atas 2 kelas, yaitu kelas VIIIa yang berjumlah 30 orang siswa sebagai kelas perlakuan model pembelajaran tipe Auditory Intelectually Repetition (AIR) dan kelas VIIIb yang berjumlah 34 orang siswa sebagai kelas perlakuan model pembelajaran tipe Think Talk Write (TTW). Teknik pengambilan sampel dilakukan secara purposive sampling, yaitu pengambilan sampel dengan cara penentuan dua unit kelas oleh pihak sekolah secara langsung.

Dari dua unit kelas tersebut diundi secara acak untu menentukan kelas yang akan menjadi kelompok eksperimen tipe Auditory Intelectually Repetition (AIR) dan yang akan menjadi kelompok tipe Think Talk Write (TTW).

Instrumen pada penelitian ini yaitu soal tes dan lembar observasi. 
Teknik pengumpulan data yang dilakukan yaitu melalui observasi dan metode tes. Observasi dilakukan untuk menentukan kelas yang akan dijadikan sebagai kelas kelompok eksperimen I dan kelas kelompok eksperimen II. Data mengenai hasil belajar biologi siswa diambil dari tes akhir belajar, dimana tes akhir belajar tersebut dibuat dalam bentuk soal pilihan ganda.

Analisis statistika deskriptif digunakan untuk mendeskripsikan skor hasil belajar biologi siswa yang diperoleh dari masing-masing kelas eksperimen penelitian (Balta, \& Sarac, H. 2016).

Analisis statistika inferensial digunakan untuk menguji hipotesis penelitian dengan menggunakan uji-t. Namun sebelum dilakukan pengujian hipotesis, dilakukan uji persyaratan analisa yaitu uji normalitas dan uji homogenitas. (Arikunto, S. 2003)

\section{HASIL DAN PEMBAHASAN}

Analisis Statistik Deskriptif Hasil Belajar Siswa dengan Menggunakan Model Pembelajaran Auditory Intelectually Repitition (AIR)
Tabel 1. Distribusi Skor Hasil Belajar

Siswa yang Diajar Menggunakan Model Pembelajaran Aditory Intelectally Repetition (AIR)

\begin{tabular}{lc}
\hline \multicolumn{1}{c}{ Statistik } & Kelompok AIR \\
\hline Jumlah data & 30 \\
Nilai maksimum & 96 \\
Nilai minimum & 51 \\
Rentangan & 45 \\
Nilai rata-rata & 76,40 \\
Standar deviasi & 14,27 \\
Variansi & 203,559 \\
\hline
\end{tabular}

Berdasarkan $\quad$ Tabel 1 . menunjukkan bahwa dari 30 siswa pada kelompok AIR yang diberi tes pada materi sistem gerak pada manusia menunjukkan bahwa skor rata- rata hasil belajar siswa adalah 76,40. Skor yang dicapai siswa dengan skor terendah adalah 51 dan skor tertinggi adalah 96. Rentang skor adalah 45 yang merupakan selisih antara skor tertinggi dan skor terendah. Selain itu, diperoleh nilai standar deviasi 14,27 serta besarnya varian yakni 203,559.

Tabel 2. Distribusi Frekuensi dan Persentase Pengkategorian Hasil Belajar Siswa dengan Menggunakan Model Pembelajaran AIR

\begin{tabular}{cccc}
\hline Interval & $\mathbf{F}$ & $\boldsymbol{\%}$ & Kategori \\
\hline $0-39$ & 0 & 0 & $\begin{array}{c}\text { Sangat } \\
\text { Rendah }\end{array}$ \\
\hline $40-55$ & 2 & 6.67 & Rendah \\
\hline
\end{tabular}




\begin{tabular}{cccc}
\hline $56-65$ & 6 & 20 & Sedang \\
\hline $66-79$ & 4 & 13.33 & Tinggi \\
\hline $80-100$ & 18 & 60 & $\begin{array}{c}\text { Sangat } \\
\text { Tinggi }\end{array}$ \\
\hline Jumlah & 30 & 100 & \\
\hline
\end{tabular}

Grafik 1. Persentase Pengkategorian Hasil Belajar Siswa Dengan Menggunakan Model Pembelajaran AIR

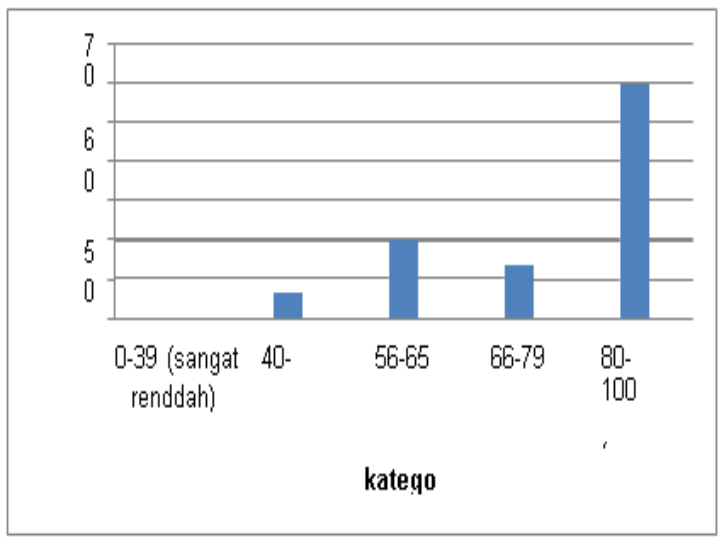

Berdasarkan data Tabel 2. dan

Grafik 1. dapat diketahui bahwa hasil belajar siswa dengan menggunakan model pembelajaran AIR diketahui tidak ada siswa yang meperoleh nilai pada kategori sangat rendah $(0 \%)$, pada kategori rendah terdapat 2 siswa $(6,67 \%)$, pada kategori sedang terdapat 6 siswa (20\%), pada kategori tinggi terdapat 4 siswa $(13,33 \%)$ dan pada kategori sangat tinggi terdapat 18 siswa (60\%). Hal ini mengindikasikan terdapat $60 \%$ siswa yang memperoleh nilai yang berkisar pada nilai $80-100$. Sehingga dapat disimpulkan bahwa hasil belajar biologi siswa pada materi sistem gerak dengan menggunakan model pembelajaran Auditory intellectually Repitition (AIR) berada pada kategori sangat tinggi. Hasil Belajar Siswa yang Diajar dengan Menggunakan Model Pembelajaran Think Talk Write (TTW)

Tabel 3. Distribusi Skor Hasil Belajar Siswa yang Diajar Menggunakan Model Think Talk Write (TTW)

\begin{tabular}{lc}
\hline Statistik & $\begin{array}{c}\text { Kelompok } \\
\text { TTW }\end{array}$ \\
\hline Jumlah data & 34 \\
\hline Nilai maksimum & 90 \\
\hline Nilai minimum & 33 \\
\hline Rentangan & 57 \\
\hline Nilai rata-rata & 64,79 \\
\hline Standar deviasi & 14,16 \\
\hline Variansi & 200,350 \\
\hline
\end{tabular}

Berdasarkan Tabel 4 . Menunjukkan bahwa kelompok TTW yang berjumlah 34 siswa yang diberi tes pada materi sistem gerak pada manusia menunjukkan bahwa skor rata-rata hasil belajar siswa adalah 64, 79 yang mengindikasikan bahwa skor hasil belajar siswa berpusat di 64, 79. Skor yang dicapai siswa dengan skor 
terendah adalah 33 dan skor tertinggi adalah 90. Rentang skor adalah 57 yang merupakan selisih antara skor tertinggi dan skor terendah. Sedangkan nilai standar deviasi adalah 14,16 serta besarnya varian yakni 200,350.

Tabel 4. Distribusi Frekuensi dan Persentase Pengkategorian Hasil Belajar

Siswa dengan Menggunakan model TTW

\begin{tabular}{clccc}
\hline No & Interval & $\mathbf{F}$ & $\%$ & Kategori \\
\hline 1 & $0-39$ & 1 & 2.94 & $\begin{array}{c}\text { Sangat } \\
\text { Rendah }\end{array}$ \\
\hline 2 & $40-55$ & 8 & 23.53 & Rendah \\
\hline 3 & $56-65$ & 10 & 29.41 & Sedang \\
\hline 4 & $66-79$ & 8 & 23.53 & Tinggi \\
\hline 5 & $80-100$ & 7 & 20.59 & $\begin{array}{c}\text { Sangat } \\
\text { Tinggi }\end{array}$ \\
\hline Jumlah & 34 & 100 &
\end{tabular}

Grafik 2. Persentase pengkategorian hasil belajar biologi siswa dengan menggunakan model pembelajaran TTW

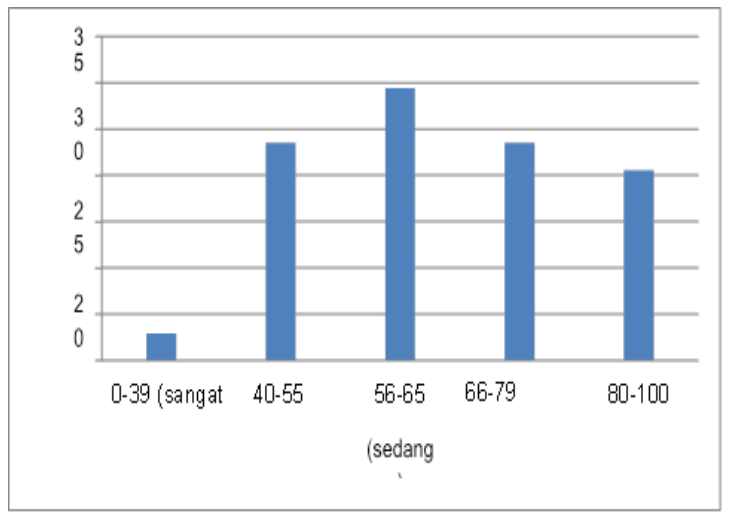

Berdasarkan data Tabel 4. dan Grafik 2. di atas dapat diketahui bahwa hasil belajar siswa dengan menggunakan model pembelajaran TTW siswa yang meperoleh nilai pada kategori sangat rendah terdapat 1 siswa $(2,94 \%)$, pada kategori rendah terdapat 8 siswa $(23,53 \%)$, pada kategori sedang terdapat 10 siswa $(29,41 \%)$, pada kategori tinggi terdapat 8 siswa $(23,53 \%)$ dan pada kategori sangat tinggi terdapat 7 siswa $(20,9 \%)$. Hal ini mengindikasikan bahwa terdapat $29,41 \%$ siswa yang memperoleh nilai yang berkisar antara 56-65. Sehinga dapat disimpulkan bahwa hasil belajar biologi siswa pada materi seistem gerak dengan menggunakan model pembelajaran Think Talk Write (TTW) berada pada kategori sedang., Analisis Statistik Inferensial

Tabel 5. Uji Normalitas

\begin{tabular}{cccc}
\hline & T & df & $\begin{array}{c}\text { Sig. (2- } \\
\text { tailled) }\end{array}$ \\
\hline Nilai & $\begin{array}{c}3.26 \\
1\end{array}$ & 62 & 0.002 \\
\hline
\end{tabular}

Berdasarkan Tabel $\quad 5$. menunjukkan bahwa nilai Kolmogorovsmirnov untuk kelompok eksperimen I yang menggunakan model pembelajaran Auditory Intelectually Repititon (AIR) 
sebesar 1,058 dengan nilai signifikan sebesar 0,213 sedangkan kelompok eksperimen II yang menggunakan model pembelajaran Think Talk Write (TTW) sebesar 0,628 dengan nilai signifikan 0,826. Kedua kelompok eksperimen memiliki nilai tingkat signifikansi di atas 0.05 (5\%). Oleh karena itu dapat dikatakan bahwa kedua kelompok eksperimen berasal dari populasi yang terdistribusi normal. Hal ini menandakan bahwa $\mathrm{H} 0$ diterima.

Tabel 6. Uji Homogenitas

\begin{tabular}{ll}
\hline & Nilai \\
\hline F & 0.077 \\
\hline Sig. & 0.782 \\
\hline
\end{tabular}

Berdasarkan Tabel 6. diperoleh nilai $F$ sebesar 0.077 dengan nilai signifikansi sebesar 0.782. Oleh karena nilai signifikansi $0.783>0.05$, maka dapat disimpulkan bahwa kedua varian sama (homogen). Berdasarkan hasil perolehan tersebut maka Ha ditolak dan H0 diterima
Tabel 7. Perbandingan Hasil Belajar Biologi Siswa Kelompok Eksperimen I dan Kelompok Eksperimen II

\begin{tabular}{lcc}
\hline & Eks_I & Eks_II \\
\cline { 2 - 3 } $\begin{array}{c}\text { Kolmogorov- } \\
\text { sminorv Z }\end{array}$ & 1.058 & 0.628 \\
\hline Sig. & 0.213 & 0.826 \\
\hline
\end{tabular}

Berdasarkan Tabel 7. hasil analisis independent samples test di atas, di peroleh nilai thitung yaitu 3.261, dengan derajat kebebasan $(\mathrm{df})=\mathrm{n}_{1}+\mathrm{n}_{2}-2$ $=30+34-2=62$ dengan nilai $t_{\text {tabel }}$ sebesar 1.66980. Oleh karena nilai thitung $>t_{\text {tabel }}$ yakni 3.261>1.66980 maka H0 ditolak atau Ha diterima. Artinya bahwa ada perbedaan antara nilai hasil belajar kelompok eksperimen I yang menggunakan model pembelajaran Aditory Intelectually Repitition (AIR) dengan kelompok eksperimen II yang menggunakan model pembelajaran Think Talk Write (TTW).

Penelitian ini dilaksanakan pada dua kelompok eksperimen yakni kelompok eksperimen I dan kelompok eksperimen II, dengan menggunakan dua model pembelajaran. Model pembelajaran yang digunakan pada kelompok eksperimen I adalah model 
pembelajaran Auditory Intellectually Repetition (AIR) sedangkan pada kelompok eksperimen II menggunakan model pembelajaran Think Talk Write (TTW). Pemilihan model pembelajaran AIR dan TTW yang diberikan kepada kelas di pilih secara acak.

Model pembelajaran sangat mendukung berjalannya proses belajar mengajar. Guru hendaknya dapat menggunakan model pembelajaran yang bervariasi dalam proses belajar mengajar sehingga siswa akan tertarik dan termotivasi untuk mengikuti proses pembelajaran. Menurut penelitian (Murti, W. 2019)

Menurut Muhama, I, Kwaw, R, Mensah, K.,J, Acheampong, E, \& Marfo, R. (2019) bahwa guru harus berusaha menyediakan lingkungan belajar yang kreatif dan kondusif dengan tujuan untuk membangkitkan minat siswa dengan menghindarkan halhal yang monoton dan membosankan. Hal ini sejalan dengan pendapat yang dikemukakan oleh Djamarah (2004) dan Monika, T.,S. (2018) bahwa guru harus memelihara minat anak didik dalam belajar, yaitu dengan memberikan kebebasan tertentu dalam situasi belajar dan memberikan cukup banyak hal yang perlu dipikirkan dan dilakukan.

Berdasarkan data yang diperoleh dari Tabel 1. distribusi skor hasil belajar siswa yang diajar menggunakan model pembelajaran Aditory Intelectally Repitition (AIR) menunjukkan bahwa nilai rata-rata siswa yaitu 76,40 . Sedangkan pada Tabel 3. distribusi skor hasil belajar siswa yang diajar menggunakan model pembelajaran Think Talk Write (TTW) menunjukkan bahwa nilai rata-rata siswa yaitu 64,79 .

Data di atas juga didukung dengan hasil olah data pada Tabel 2 . distribusi frekuensi dan persentase pengkategorian hasil belajar siswa dengan menggunakan model pembelajaran AIR menunjukkan bahwa hasil belajar siswa yang diajar dengan menggunakan model pembelajaran AIR berada pada kategori sangat tinggi dengan persentase sebesar $60 \%$. Sedangkan pada Tabel 4. distribusi frekuensi dan persentase pengkategorian hasil belajar siswa dengan menggunakan model TTW menunjukkan bahwa hasil belajar siswa 
yang diajar menggunakan model pembelajaran TTW yang berada pada kategori sangat tinggi memiliki persentase sebesar $20,59 \%$.

Berdasarkan uraian data di atas, dapat diketahui bahwa model pembelajaran Auditory Intelectually Repititon (AIR) lebih tepat untuk digunakan dalam pembelajaran biologi pada materi sistem gerak pada manusia.

Hasil penelitian ini didukung dengan penelitian terdahulu yang dilakukan oleh Pujiastutik, Hendrik. (2017), bahwa dengan penerapan model AIR (Auditory, Intellectualy, Repetition) dalam pembelajaran, maka didapatkan hasil belajar yag baik pada mahasiswa. Dalam pembelajaran AIR, mahasiswa dituntut untuk mnedengarkan, menyelidiki dan melatih suatu informasi yang telah diperoleh dengan pemberian tugas atau kuis, sehingga mahasiswa dapat meningkaktkan kemampuannya dan dapat pula meningkatkan nilai belajarnya. Tercapainya hasil belajar yang meningkat pada mata kuliah belajar pembelajaran dengan menggunakan model pembelajaran AIR
(Auditory, Intellectualy, Repetition) dikarenakan mahasiswa menjadi lebih aktif, khususnya dalam mendengarkan, berbicara, memberikan ide atau argumentasi secara lisan (Auditory), mampu memecahkan suatu masalah (Intellectualy) serta mampu memantapkan pemahaman yang diperoleh selama pembelajaran melalui bentuk pengulangan (Repetition) yang berkaitan dengan materi teori pembelajaran yang telah dipelajari.

Sejalan dengan hasil penelitian Sakti, H.G., Hikayati, S. (2017), bahwa ada pengaruh penggunaan model pembelajaran AIR (Auditory, Intellectualy, Repetition) terhadap hasil belajar mata pelajaran matematika pada siswa kelas VII SMP Negeri 2 Lembar Lombok Barat tahun pelajaran 2016/2017.

Berdasarkan Tabel 7. hasil analisis independent samples test, di peroleh nilai thitung yaitu 3.261, dengan derajat kebebasan $(\mathrm{df})=\mathrm{n} 1+\mathrm{n} 2-$ $2=30+34-2=62$ dengan nilai ttabel sebesar 1.66980. Oleh karena nilai thitung >ttabel yakni 3.261>1.66980 maka HO ditolak atau $\mathrm{Ha}$ diterima. 
Artinya bahwa ada perbedaan antara nilai hasil belajar kelompok eksperimen I yang menggunakan model pembelajaran Aditory Intelectually Repitition (AIR) dengan kelompok eksperimen II yang menggunakan model pembelajaran Think Talk Write (TTW).

Adapun hasil penelitian lain yang mendukung yakni penelitian yang dilakukan oleh Yuwanda, M., Chotimah, U., Waluyati, S.A. (2017), dan Maharlika, A. R, Santosa S, B \& Prayitno, B. A. 2018 bahwa ada pengaruh yang signifikan dari penerapan Model Pembelajaran Auditory Intellectually Repetition terhadap hasil belajar siswa pada matapelajaran PPKn di kelas VIII SMP Negeri 1 Palembang”.

\section{KESIMPULAN}

Berdasarkan hasil analisis data dan pembahasan, maka dapat disimpulkan bahwa ada perbedaan hasil belajar biologi siswa kelas VIII SMP Negeri 5 Bittuang yang diajar melalui model pembelajaran Auditory Intelectualy Repetition (AIR) dan
Model Pembelajaran Think Talk Write (TTW) pada Materi Sistem Gerak.

\section{UCAPAN TERIMA KASIH}

Penulis mengucapkan terima kasih kepada semua pihak yang turut membantu dalam penyusunan dan penyelesaian hasil penelitian ini. Terkhusus kepada pimpinan STKIP Pembangunan Indonesia yang telah memberikan saya wadah untuk bisa melakukan penelitian ini.

\section{DAFTAR PUSTAKA}

Arikunto, S. 2003. Prosedur Penelitian Suatu Pendekatan Praktik. Jakarta: Rineka Cipta.

Balta, \& Sarac, H. 2016. The Effect of $7 E$ Learning Cycle on Learning in Science Teaching: A MetaAnalysis Study. European Journal of Educational Research, 5(2), 61-72. https://doi.org/10.12973/eujer.5.2.61.

Djamarah. 2004. Psikologi Belajar. Jakarta: Raneka Cipta.

Elinawati, W., Duda, H.J. \& Julung, H. 2018. Penerapan Model Pembelajaran Auditory Intellectually Repetition (Air) Terhadap Hasil Belajar Kognitif Siswa. Jurnal Sainsmat (Online), 7 (1): 35-49. 
DOI: https://doi.org/10.35580/sa insmat7164722018

Fahri, M. B. P. (2014). Penerapan Model Problem Based Learning (PBL) Untuk Meningkatkan Hasil Belajar Siswa Pada Materi Panjang Garis Singgung Persekutuan Dua Lingkaran di Kelas VIII SMP Negeri 19 Palu. Jurnal Elektronik Pendidikan Matematika Tadulako, 2(1),67-77. http://jurnal.untad.ac.id/jurnal/in dex.php/JEPMT/article/view/32 32.

Fikri, B. M. (2014). Penerapan Model Pembelajaran Problem Based Learning Untuk Meningkatkan Hasil Belajar Siswa Kelas VIII SMP Negeri 4 Palu Pada Materi Prisma. Jurnal Elektronik Pendidikan Matematika Tadulako, 2(1), 45-54. http://jurnal.untad.ac.id/jurnal/in dex.php/JEPMT/article/view/32 30 .

j, O., \& Saka, A. Z. 2015. Development of Teacher Guidance Materials Based on 7E Learning Method in Virtual Laboratory Environment. Procedia Social dan Behavioral Sciences, 191, 810-827. https://doi.org/10.1016/j.sbspro. 2015.04.524.

Maharlika, A. R, Santosa S, B \& Prayitno, B. A. 2018. Pengaruh Model Pembelajaran Kooperatif Tipe Think, Talk, Write (TTW) yang Dipadu dengan Media
Buku Komik Biologi terhadap Hasil Belajar Siswa SMA. Proceeding Biology Education Conference. 15(1): 309-316. https://jurnal.uns.ac.id/prosbi/art icle/view/32448/21530

Muhama, I, Kwaw, R, Mensah, K.,J, Acheampong, E, \& Marfo, R. 2019. Relationship of Creative Thinking with the Academic Achievements of Secondary School Students. International Interdisciplinary Journal of Education, Society and Behavioural Science 31(4), 110.

DOI: 10.9734/JESBS/2019/v31i43 $\underline{0159}$

Murti, W. 2019. Pengaruh Perilaku Belajar Terhadap Prestasi Belajar IPA Biologi. Jurnal Binomial. 2 (1): 54-63. https://ejournals.umma.ac.id/ind ex.php/binomial/article/view/18 5

Musanna, Al. 2017. Indigenisasi Pendidikan: Rasionalitas Revitalisasi Praksis Pendidikan Ki Hadjar Dewantara. Jurnal Pendidikan dan Kebudayaan (Online), Volume 2 (1): 30-44. https://jurnaldikbud.kemdikbud. go.id/index.php/jpnk/article/vie w/529.

Monika, T., S. 2018. Perbedaan Kemampuan Pemecahan Masalah Matematis Dan Sikap Siswa Yang Diberi Pembelajaran Kooperatif Tipe Think Pair Share Dengan Tipe 
Think Pair Square Pada SMP Negeri Pematangsiantar. Jurnal MES (Journal of Mathematics Education and Science). 3 (2): 102-111.

https://repository.uhn.ac.id/bitstr eam/handle/123456789/1410/JU RNAL\%20MES.pdf?sequence= $\underline{1 \& \text { isAllowed }=\mathrm{y}}$

Pujiastutik, H. 2016. Penerapan Model Pembelajaran AIR (Auditory, Intellectualy, Repetition) untuk Meningkatkan Hasil Belajar Mahasiswa. Proceeding Biology Education Conference (Online), 13(1): 515-518 https://jurnal.uns.ac.id/prosbi/iss ue/view/728.

Sakti, H.G. \& Hikayati, S. 2017. Pengaruh Penggunaaaan Model Pembelajaran Air (Auditory, Intellectualy, Repetition) Terhadap Hasil Belajar Mata Pelajaran Matematika Pada Siswa Kelas VII SMP Negeri 2 Lembar Lombok Barat Tahun Pelajaran 2016/2017. Jurnal Jurusan Pendidikan IPS Ekonomi. 8 (2): 65-75. https://journal.uinmataram.ac.id/ index.php/society/article/view/1 $\underline{505}$

Trianto. 2010. Mendesain Model Pembelajaran Inovatif Progesif. Jakarta: Bumi Aksara.

Undang-undang No. 20 Tahun 2003 tentang Sistem Pendidikan Nasional. Jakarta: Depdiknas.

Wasti, S., Rahmiati \& Izwerni. 2013. Hubungan Minat Belajar
Dengan Hasil Belajar Mata Pelajaran Tata Busana di Madrasah Aliyah Negeri 2 Padang. E-Journal Home Economic and Tourism, 2 (1): 114. http://ejournal.unp.ac.id/index.p hp/jhet/article/view/1032

Winarti, A. 2018. Model Pembelajaran Think Talk Write Meningkatkan Prestasi Belajar Mata Pelajaran IPA SD. Jurnal Pendidikan: Riset \& Konseptual. 2 (3): 45-55 (http://journal.unublitar.ac.id/pe ndidikan/index.php/Riset_Konse ptual.

Yuwanda, M., Chotimah, U. \& Waluyati, S.A. 2017. Pengaruh Penerapan Model Pembelajaran Auditory Intellectually Repetition (AIR) terhadap hasil belajar siswa pada mata pelajaran ppkn di kelas VIII SMP Negeri 1 Palembang. Jurnal Bhinneka Tunggal Ika. 4 (1):

13-22. https://ejournal.unsri.ac.id/index. php/jbti/article/view/4606 